\title{
The Role of Cultural Capital in Strengthening the Relationship between Need and Demand for Contraceptive Devices and Drugs in Several Cultural Areas in Indonesia
}

\author{
Lamia Diang Mahalia $^{1,2}$, Stefanus Supriyanto ${ }^{3 *}$ \\ ${ }^{1}$ Doctoral Program of Public Health, Faculty of Public Health, Universitas Airlangga, Surabaya, Indonesia; ${ }^{2} \mathrm{Health}$ Polytechnic \\ Ministry of Health, Palangka Raya, Indonesia; ${ }^{3}$ Department of Health Policy and Administration, Faculty of Public Health, \\ Universitas Airlangga, Surabaya, Indonesia
}

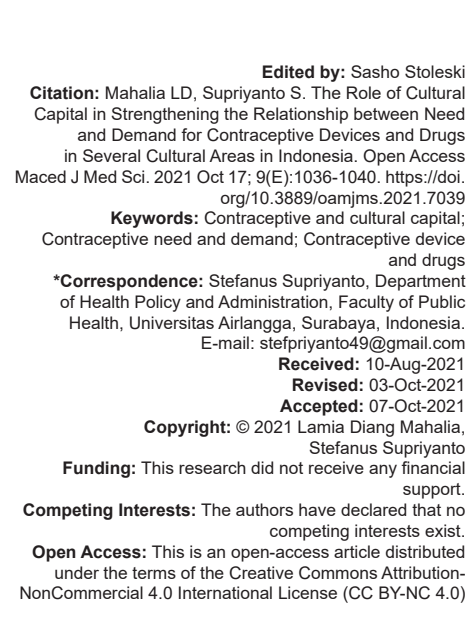

\section{Introduction}

As social beings, human life cannot be separated from cultural influences [1]. Every couple who uses contraceptive devices/drugs is founded by a clear need [2]. One of the factors affecting the acceptors' decision to use contraceptive devices/drugs is culture [3].

The question raised regarding whether the contraceptive devices/drugs they use really suits his needs can be influenced by the cultural factors. Pierre Bourdieu divided cultural capital into three forms, namely the embodied state, objectified state, and institutionalized state [4], [5]. The embodied state is related to the convenience of using contraceptive devices/drugs to the acceptor's body. The objective state is related to the safety of the contraceptive devices/ drugs used, while the institutionalized state is related to institutional support for the acceptors' participation in the Family Planning program.

Each ethnic group has a unique culture. Indonesia, as a multicultural or multi-ethnic country, has a very large number of ethnic groups. The differences between ethnic groups in Indonesia can be seen in all their activities and social interactions, including the need and demand for contraceptives. Ethnographic benchmarks emphasize the cultural aspects inherent in a social system. Some examples of ethnic groups in Indonesia whose populations are quite large are Dayak and Javanese [6], [7], [8]. The growing multicultural demographics of public health status have challenged health systems to consider cultural competence as a priority [9]. Therefore, the researcher tried to analyze the influence of culture as a moderating variable on the relationship between need and demand for contraceptive devices/drugs in several cultural areas in Indonesia. The results of this 
study are expected to become input to the relevant government in making a strategy for handling the problem of population through the use of contraceptive devices/drugs suitable for the acceptor's needs using a cultural capital approach.

\section{Material and Methods}

This research was done by using an observational approach with cross-sectional design. The study was conducted in Central Kalimantan Province from September to October 2020. The criteria for the research subjects were: (1) Women of reproductive age who were using contraceptive devices/drugs of IUD, implants, pills, or injections; (2) Aged 15-49 years old; and (3) Indonesian citizens who come from Dayak and Javanese cultural areas.

Sampling was performed through a multistage random sampling technique consisting of four steps, namely: (1) Identifying and determining districts in Central Kalimantan that have different cultures; (2) Identifying and determining the sub-districts based on its culture; (3) Identifying and determining the village/ sub-village in each sub-district; and (4) Determining the sample size of each village/sub-village. Data were obtained by using a questionnaire. The questionnaires results were then analyzed using the univariate analysis and presented in the form of a frequency distribution table, and multivariate analysis using the Partial Least Square (PLS) statistical test.

\section{Results}

\section{Embodied state}

The embodied state is an intrinsic factor in a person's self or body that is related to the convenience of using contraceptive devices/drugs to the acceptor's body. The results of the frequency distribution of respondents' answers about cultural capital based on the embodied state category (Table 1) indicate that the highest frequency of answers is that respondents felt very comfortable with the contraceptive devices/drugs used.

Table 1: The Distribution of cultural capital frequencies based on embodied state categories among respondents in Dayak and Javanese cultural areas

\begin{tabular}{|c|c|c|c|c|c|c|}
\hline \multirow[t]{2}{*}{ Embodied State } & \multicolumn{2}{|c|}{ Dayak } & \multicolumn{2}{|c|}{ Javanese } & \multicolumn{2}{|c|}{ Total } \\
\hline & $\mathrm{n}$ & $\%$ & $\mathrm{n}$ & $\%$ & $\mathrm{n}$ & $\%$ \\
\hline Quite comfortable & 0 & 0.0 & 1 & 3,1 & 1 & 1.5 \\
\hline Comfortable & 7 & 20.6 & 8 & 25.0 & 15 & 22.7 \\
\hline Very comfortable & 27 & 79.4 & 23 & 71.9 & 50 & 75.8 \\
\hline Total & 34 & 100.0 & 32 & 100.0 & 66 & 100.0 \\
\hline
\end{tabular}

Table 2: Distribution of cultural capital frequencies based on objectified state categories among respondents in Dayak and Javanese cultural areas

\begin{tabular}{|c|c|c|c|c|c|c|}
\hline \multirow[t]{2}{*}{ Objectified state } & \multicolumn{2}{|c|}{ Dayak } & \multicolumn{2}{|c|}{ Javanese } & \multicolumn{2}{|c|}{ Total } \\
\hline & $\mathrm{N}$ & $\%$ & $\mathrm{~N}$ & $\%$ & $\mathrm{n}$ & $\%$ \\
\hline Quite safe & 1 & 2.9 & 0 & 0.0 & 1 & 1.5 \\
\hline Secure & 6 & 17.6 & 14 & 43.8 & 20 & 30.3 \\
\hline Very safe & 27 & 79.4 & 18 & 56.3 & 45 & 68.2 \\
\hline Total & 34 & 100.0 & 32 & 100.0 & 66 & 100.0 \\
\hline
\end{tabular}

\section{Objectified state}

The objectified state is the possession of contraceptive devices/drugs related to the safety of the contraceptive devices/drugs used. The results of the frequency distribution of respondents' answers about cultural capital based on the objectified state categories (Table 2) indicate that the most answers is that respondents felt very safe in using contraceptive devices/drugs.

\section{Institutionalized state}

Institutionalized state is related to institutional support to the acceptor's participation in the Family Planning program. This institutional support includes support from the local governments, midwives, family planning field officers, family planning cadres, community and religious leaders, as well as friends and neighbors. This form of support can be provided through health promotion efforts, to increase acceptors' motivation in striving for optimal health and to support them in using contraceptives toward a better health condition [10]. The results of the frequency distribution of respondents' answers about cultural capital based on the institutionalized state categories (Table 3) indicate that the highest frequency of answers is that respondents were supported to use contraceptive devices/drugs.

Table 3: Distribution of the cultural capital frequency based on the institutionalized state categories among respondents in Dayak and Javanese cultural areas

\begin{tabular}{|c|c|c|c|c|c|c|}
\hline \multirow[t]{2}{*}{ Institutionalized state } & \multicolumn{2}{|c|}{ Dayak } & \multicolumn{2}{|c|}{ Javanese } & \multicolumn{2}{|c|}{ Total } \\
\hline & $n$ & $\%$ & $\mathrm{n}$ & $\%$ & $n$ & $\%$ \\
\hline Quite supported & 0 & 0.0 & 0 & 0.0 & 0 & 0.0 \\
\hline Supported & 16 & 47.1 & 20 & 62.5 & 36 & 54.5 \\
\hline Strongly supported & 18 & 52.9 & 12 & 37.5 & 30 & 45.5 \\
\hline Total & 34 & 100.0 & 32 & 100.0 & 66 & 100.0 \\
\hline
\end{tabular}

\section{Model analysis using partial least square (PLS) statistical test}

The model analysis was performed using the Partial Least Square (PLS) statistical test to examine the effect of cultural capital moderating variables on the relationship between the need and demand for contraceptive devices/ drugs. Model analysis was carried out through the initial model evaluation stage and hypothesis testing.

\section{Evaluation of the initial model}

The initial model evaluation was made using the PLS statistical test. The results figure of the initial model evaluation is presented in Figure 1. 


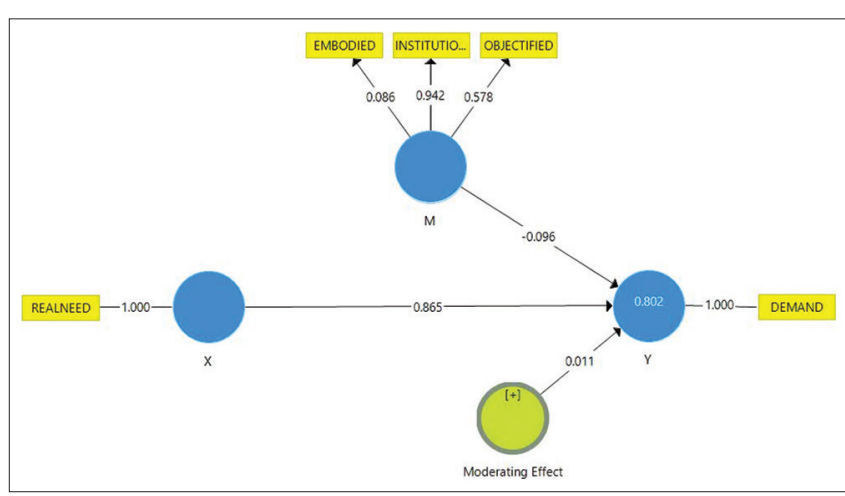

Figure 1: Initial model evaluation model

Based on the value of Construct Reliability and Validity, it was known that the Average Variance Extracted (AVE) value of the latent variable $M$ has not been fulfilled (not yet fit), so the smallest outer loading value, which is embodied, must be removed from the model. After the embodied state variable indicator was removed, a valid structural model was obtained in which the Average Variance Extracted (AVE) value in the latent variable M was fit. The values of Construct Reliability and Validity of the valid structural models are presented in Table 4.

Table 4: The value of construct reliability and validity of valid structural model

\begin{tabular}{lllll}
\hline Variable & $\begin{array}{l}\text { Cronbach's } \\
\text { alpha }\end{array}$ & rho_A & $\begin{array}{l}\text { Composite } \\
\text { reliability }\end{array}$ & $\begin{array}{l}\text { Average variance } \\
\text { extracted (AVE) }\end{array}$ \\
\hline $\mathrm{M}$ & 0.465 & 0.721 & 0.760 & 0.626 \\
Moderating effect 1 & 1.000 & 1.000 & 1.000 & 1.000 \\
$\mathrm{X}$ & 1.000 & 1.000 & 1.000 & 1.000 \\
$\mathrm{Y}$ & 1.000 & 1.000 & 1.000 & 1.000 \\
\hline
\end{tabular}

Further testing was then carried out against the valid structural model, namely hypothesis testing. The valid structural model is presented in Figure 2.

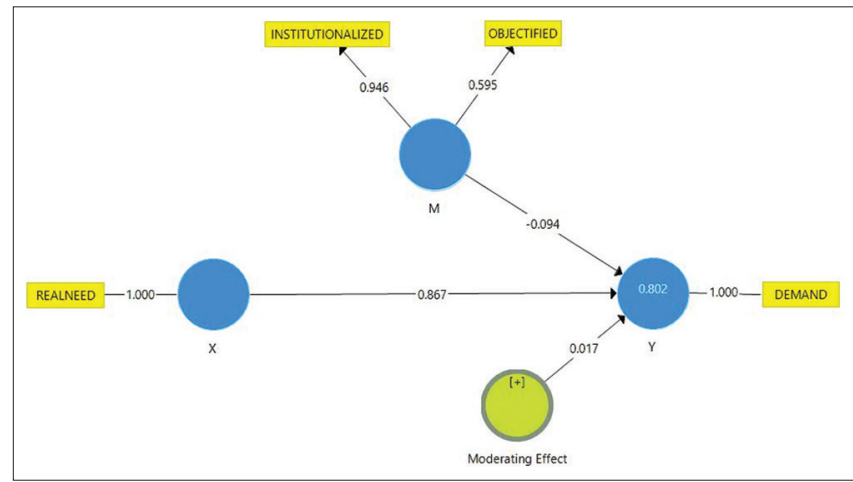

Figure 2: The valid structural model

\section{Hypothesis testing}

The influence of the cultural capital moderating variable on the relationship between the need and

Table 5: The p-value on the influence of cultural capital moderator variables on the relationship between need and demand in Dayak and Javanese cultural areas.

\begin{tabular}{llll}
\hline Path & $\begin{array}{l}\text { Original sample } \\
(\mathrm{O})\end{array}$ & $\mathrm{p}$-value & Significance \\
\hline $\begin{array}{l}\text { Cultural capital } \\
\text { (objectified state, institutionalized }\end{array}$ & -0.094 & 0.113 & Not significant \\
state $) \rightarrow \square$ Demand & & & \\
$\begin{array}{l}\text { Moderating effect } \rightarrow \square \text { Demand } \\
\text { Need } \rightarrow \square \text { Demand }\end{array}$ & 0.017 & 0.722 & Not significant \\
\hline
\end{tabular}

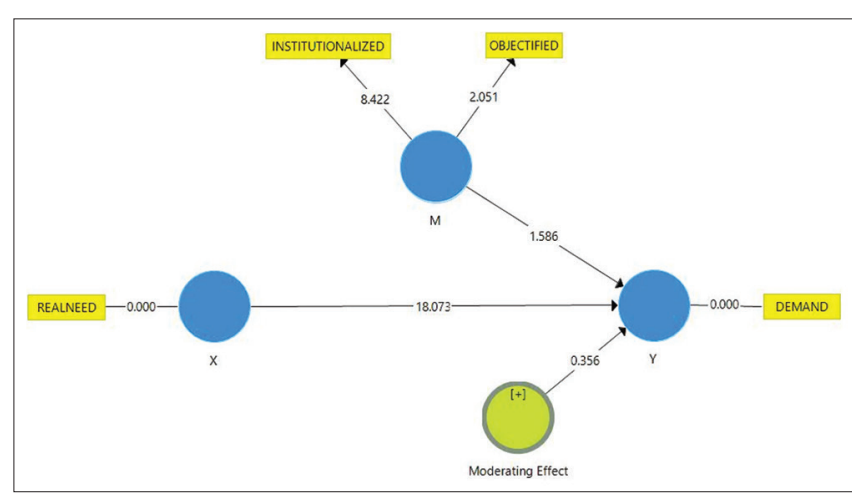

Figure 3: The fit model of the cultural capital influence on the relationship between need and demand for contraceptive devices/drugs in Dayak and Javanese cultural areas

demand for contraceptive devices/drugs in Dayak and Javanese cultural areas presented in Figure 3 can be further explained in Table 5.

The results of hypothesis testing as presented in Figure 3 and Table 5 can be further explained as follows:

1. The relationship between need and demand is significant with a p-value of 0.000 . Thus, the results of statistical tests showed that there was a significant relationship between the need and demand for contraceptive devices/drugs. The amount of influence between the need and the demand shown by the $R^{2}$ value was 0.792 , indicating that the effect between the need and the demand is equal to $79.2 \%$.

2. Cultural capital (objectified state and institutionalized state) had no significant correlation with the demand $(p=0.113)$, and had no significant moderating effect value $(p=0.722)$. Thus, the results of statistical tests showed that culture (objectified state and institutionalized state) is a variable that has the potential to become a moderating variable (homologous moderator) which can influence the strength of the relationship between need and demand for contraceptive devices/drugs [11]. The original sample value was 0.017 , meaning that the moderating cultural capital variable strengthened the relationship between the need and demand for contraceptive devices/drugs.

\section{Discussion}

Need and demand for contraceptive devices/ drugs had a significant relationship where the strength of the relationship is influenced by the cultural capital moderating variable. This finding was supported by several research related to need, demand, and supply chain management. The balance between need and demand will ultimately affect the supply of contraceptives 
so that they can meet the needs of acceptors [12], [13]. The acceptor has needs, wants, and necessities, all of which require fulfillment in the form of goods, including contraceptive devices/medicines. The use of contraceptives devices/drugs will cause desire, and this desire will in turn generate demand. One of the efforts that the government can make in the success of the family planning program is to identify the needs of acceptors through a cultural capital approach so that they can use contraceptive devices/drugs that suit their needs [14], [15], [16], [17]. The understanding about cultural factors can help health workers and policymakers in educating the public about the importance of health, including the use of contraceptives [18].

The influence of cultural capital on the relationship between need and demand for contraceptive devices/drugs is viewed from three aspects, namely the embodied state, objectified state, and institutionalized state [19]. Culture plays a role in determining a person's behavior for family planning [20]. The results showed that culture (objectified state and institutionalized state) is a variable that has the potential to become a moderating variable in influencing the strength of the relationship between need and demand for contraceptive devices/drugs.

The objective state of cultural capital refers to "cultural goods" where in this study, it refers to contraceptive devices/drugs. The objectified state is the possession of contraceptive devices/drugs related to the safety of the contraceptive devices/ drugs used [19], [21], [22]. Acceptors are more interested in using contraceptive devices/drugs after knowing the practical benefits and safety level of contraceptives that will affect their bodies. This shows that the acceptors' knowledge/understanding of the benefits and side effects of allocones play a role in forming the objectified state [23]. The safety in question is the acceptor's perception when seeing or witnessing the effects of using the type of contraceptive devices/drugs used, such as making the acceptor's body fat [24].

In general, people follow the culture and customs that have been formed since a long time ago. Culture can influence a person's decision to use contraceptive devices/drugs. Culture is a set of values, norms, and symbols that have meanings, shaping human behavior and are passed down from one generation to the next generation. Culture is a very important concept for understanding the acceptor behavior. The basic of the acceptor's desire is culture. The more acceptors who choose a type of contraceptive devices/drugs, the more it can influence people's behavior in determining the type of contraceptive devices/drugs used [4], [25], [26].

Institutionalized state is associated with the institutional support of the acceptor participation in family planning. The support referred to comes from the local government, midwives, family planning field officers, family planning cadres, community leaders and religious leaders, as well as neighbors and friends. Health workers such as midwives play an important role than Family Planning Field Officers in providing information about contraceptive methods to prospective acceptors [26]. Therefore, in addition to the support of Family Planning Field Officers, support from midwives is also very much needed to stimulate the community to use contraceptive devices/medicines according to their needs. In addition, health workers can be a reference for the community to use contraceptive devices/drugs [27] health workers who do not use contraceptive devices/drugs can become reinforcing factors that can affect the use of contraceptive devices/drugs in the community [25], [28].

Reference groups such as community and religious leaders also influence the acceptors' decision to use contraceptive devices/drugs [24]. Norms are believed by the reference group to be able to limit or stimulate acceptors' behavior and influence acceptors' opinions in using contraceptive devices/drugs. Their community or religious leaders who disagree with the Family Planning program can hinder the success of the program [29]. Therefore, promotion to community and religious leaders can be carried out so that they can provide positive support to the community to use contraceptive devices/drugs [24], [30].

The people around the acceptors also influence the decision to use contraceptive devices/ drugs. Acceptors interact with the people around them such as neighbors and friends where they can influence each other in shaping behavior, habits, attitudes, beliefs and values that are considered important [4]. The presence of social norms and values in society that cannot accept birth spacing program and considers it incompatible with the values believed by the public can become an obstacle for the Family Planning program. This can be due to cultural factors in the community that are still thick and difficult to accept reforms that they consider not in accordance with their values and social norms [29]. Communication and interactions patterns with friends and neighbors can influence acceptors' beliefs and attitudes about effective contraceptive devices/ drugs that are according to their needs so that in the end it will influence the acceptors' decisions to use contraceptive devices/drugs [25], [31].

\section{Conclusion}

There is a significant relationship between need and demand for contraceptive devices/drugs. Culture (objectified state and institutionalized state) is a variable that has the potential to become a moderating 
variable which can weaken the relationship between need and demand for contraceptive devices/drugs. Therefore, a cultural approach is needed so that acceptors can use contraceptive devices/drugs that really suit their needs.

\section{Acknowledgment}

The authors are grateful to Faculty of Public Health Universitas Airlangga, College of Pharmacy Palangka Raya.

\section{References}

1. Kotler P. Marketing Management: Analysis, Planning, Implementation and Control. Jakarta: Prenhallindo; 2015.

2. Agustini $R$, Wati DM, Ramani A. Kesesuaian penggunaan alat kontrasepsi berdasarkan permintaan $\mathrm{KB}$ pada pasangan usia subur (PUS) di Kecamatan Puger Kabupaten Jember (Contraceptives use compatibility based on contraceptive demand among fertile age couple at Puger sub district, Jember Dist. Pustaka Kesehatan. 2015;3(1):155-62.

3. Bourdieu P. The forms of capital. In: Richardson JG, editor. Handbook of Theory and Research for the Sociology of Education. New York: Greenwood; 1986. p. 241-58.

4. Rusman MR. Budaya Dan Kontrasepsi. Penerbit Qiara Media; 2020.

5. Mishra S. Pierre bourdieu cultural social capital. Res J Hum Soc Sci. 2012;3(2):293-8

6. Kamarusdiana. Community and cultural framework in ethnographic studies. J Sosial Budaya Syar-i. 2019;6(2):113-28.

7. Darmadi H. Dayak and their daily life. J Educ Teach Learn. 2017;2(1):42-6

8. Geertz C. Culture and social change: The Indonesian case. Man. 1984;1:511-32.

9. Xavier BC. Ethno psychology and its application-review. Res J Hum Soc Sci. 2016;7(4):325-36.

10. Prakash KS, Pavan K, Sunil R, Kumar, Abhishek, Poonam P, et al. A Preface noesis regarding general health awareness among the rural mass. Asian J Pharm Technol. 2012;2(1):12-4.

11. Sharma S, Durand RM, Gur-Arie O. Identification and analysis of moderator variables. J Market Res. 1981;18(3):291-300.

12. Joshi V. Supply chain management a pathway for economic development of SME's in India. Asian J Manag. 2018;9(1):745-51.

13. Jha M. A strategic framework for design and implementation of sustainable reverse supply. Asian J Manag. 2015;6(4):342-6.

14. Rosyidi, S. Introduction to Economic Theory: Approaches to Micro and Macroeconomic Theory. $4^{\text {th }}$ ed. Jakarta: PT Raja Grafindo Persada; 2000.

15. Ritter A, Mellor R, Chalmers J, Sunderland M, Lancaster K. Key considerations in planning for substance use treatment:
Estimating treatment need and demand. J Stud Alcohol Drugs Suppl. 2019;s18:22-30.

16. Motlaq $M E$, Eslami $M$, Yazdanpanah $M$, Nakhaee $N$. Contraceptive use and unmet need for family planning in Iran. Int J Gynecol Obstet. 2013;121(2):157-61. PMid:23473347

17. Kumar MP. Effective supply chain management equilibrates the supply and demand management of an organization. Asian $\mathrm{J}$ Manag. 2016;7(3):231-5.

18. Venkatraju B. Socio-cultural influences on patient delays in seeking treatment for TB symptoms: A qualitative study on rural TB patients in Andhra Pradesh. Res $\mathrm{J}$ Hum Soc Sci. 2013;4(1):12-21.

19. Bourdieu P. The Forms of Capital. Handbook of Theory and Research for the Sociology of Education. Vol. 241. New York, Greenwood: JG Richardson; 1986. p. 258.

20. Gogoi M. Perception and practice of family planning: An anthropological study among the assamese caste hindus and muslim population in Goalpara district, Assam. Res J Pharm Technol. 2019;12(1):324-30.

21. Kraaykamp G, Van Eijck K. The intergenerational reproduction of cultural capital: A threefold perspective. Soc Forces. 2010;89(1):209-31.

22. Rasyida AU. Communication Strategy Model of Family Planning Participation of Intrauterine Device and Implant Method in Cultural Areas of Mataraman, Arek, and Madura in East Java Province, Surabaya: Fakultas Kesehatan Masyarakat Universitas Airlangga; 2019.

23. Renuka R, Jeyarathnam M. Women's autonomy and family planning practices among married women in Coimbatore. Asian J Nurs Educ Res. 2016;6(2):214-6.

24. Supriyanto S, Ernawaty E. Health Services Industry Marketing. Yogyakarta: Penerbit ANDI; 2010.

25. Assalis $\mathrm{H}$. The correlation of socio-culture with selection methods of contraception. J Kesehatan. 2019;6(2):142-7.

26. Weaver EH, Frankenberg E, Fried BJ, Thomas D, Wheeler SB, Paul JE. Effect of village midwife program on contraceptive prevalence and method choice in Indonesia. Stud Fam Plan. 2013;44(4):389-409. http://doi. org/10.1111/j.1728-4465.2013.00366.x PMid:24323659

27. Rathore I. A study to assess the family planning practices among the married women in the reproductive age group (15-49 years) of selected villages in Oachghat, Solan (HP) in 2016. Asian J Pharm Technol. 2016;6(4):266-72.

28. Devy SR, Aji B. Faktor predisposing, enabling dan reinforcing pada pasien di pengobatan alternatif radiesthesi medik metode romo h. loogman di Purworejo Jawa Tengah. Indones J Public Health. 2006;3(2):3863.

29. Darmawati D, Rakhmah AN. The participation of family planning acceptors in couples of reproductive age in terms of sociocultural aspects. Idea Nurs J. 2017;8(1):58-62.

30. Patra S, Singh RK. Addressing unmet need and religious barrier towards the use of family planning method among Muslim women in India. Int J Hum Rights Healthc. 2015;8(1):22-35. https://doi.org/10.1108/ljhrh-06-2014-0010.

31. Ayanore MA, Pavlova M, Groot W. Context-specific factors and contraceptive use: A mixed method study among women, men and health providers in a rural Ghanaian district. Afr J Reprod Health. 2017;21(2):81-95. 